\title{
Pengembangan Kategori Edukasi Berkelanjutan dalam Penilaian Green Campus di Indonesia
}

\author{
IRVAN QOMARUZZAMAN', RINDU EVELINA', MIA WIMALA²,
}

1. Jurusan Teknik Sipil Institut Teknologi Nasional

2. Jurusan Teknik Sipil Universitas Katolik Parahyangan

Email: miasoejoso@unpar.ac.id

\begin{abstract}
ABSTRAK
Green campus adalah konsep yang memanfaatkan kampus sebagai media untuk mengintegrasikan ilmu pengetahuan keberlanjutan ke dalam kebijakan, manajemen maupun kegiatan perguruan tinggi. Berdasarkan standar yang telah ada, edukasi menjadi hal mendasar yang dipertimbangkan dalam penilaian suatu green campus. Dengan perkembangan isu keberlanjutan yang sangat pesat, penelitian ini bertujuan untuk mengembangkan kategori Education (ED) dari UI GreenMetric untuk menjadi standar yang lebih efektif. Pengembangan kategori dilakukan dengan membandingkannya dengan kategori sejenis dari STARS. Pembobotan ulang terhadap sub kategori, beserta indikator dan sub indikator baru selanjutnya dilakukan menggunakan metode Analytical Hierarchy Process. Empat sub kategori yang berhasil dikembangkan meliputi Akademik Berkelanjutan, Pengembangan Profesional Berkelanjutan, Dukungan Berkelanjutan, dan Penilaian Berkelanjutan. Studi kasus di Universitas Katolik Parahyangan juga dilakukan untuk tujuan verifikasi dari kategori Edukasi Berkelanjutan (EB) yang baru.
\end{abstract}

Kata kunci: green campus, standar penilaian, UI GreenMetric, STARS

\begin{abstract}
Green campus is a concept that leverages the campus as a medium to integrate the concept of sustainability into policy, management and university activities. Based on existing standards, education has been regarded as one of the fundamental things considered in green campus assessment both in Indonesia and in some other countries. With the rapid development of sustainability issues in recent years, this research aims to develop GreenMetric UI into a more effective green campus assessment standard, focusing on the Education (ED) category. The development of this ED category was done by comparing it with similar categoriesof STARS, the green campus standard in the United States. The re-weighting of sub categories, together with the new indicators and subindicators contained in this category, was subsequently carried out using the Analytic Hierarchy Process method. The four sub-categories which were successfully developed in this research include Sustainable Academic, Sustainable Professional Development, Sustainable Support, and Sustainable Assessment. For verification purpose, a study on campus performance at Universitas Katolik Parahyangan was conducted using the newly developed category.
\end{abstract}

Kata Kunci: green campus, asssessment standard, UI GreenMetric, STARS 


\section{PENDAhUlUAN}

Saat ini, isu pemanasan global bukan lagi menjadi wacana yang hangat dibicarakan melainkan sudah dapat dirasakan dampaknya oleh penduduk di seluruh muka bumi ini. Akar permasalahan ini berasal dari meningkatnya konsentrasi gas rumah kaca akibat aktivitas harian manusia yang terperangkap di lapisan atmosfer. Pada tahun 2014, carbondioxide $\left(\mathrm{CO}_{2}\right)$ menyumbang kontribusi sebesar $76 \%$ dari keseluruhan emisi gas rumah kaca global, diikuti oleh methane $\left(\mathrm{CH}_{4}\right)$ sebanyak $16 \%$, nitrous oxide $\left(\mathrm{NO}_{x}\right)$ sebanyak $6 \%$, dan F-gases sebanyak 2\% (IPCC, 2014). Berbagai macam usaha dilakukan sebagai wujud kepedulian yang menghasilkan beberapa pendekatan yang berkaitan dengan sustainable development dalam upaya memerangi pemanasan global. Salah satu pendekatan yang akan dibahas pada penelitian ini adalah green campus.

Perguruan tinggi sampai saat ini masih diharapkan untuk membawa perubahan yang lebih baik dalam masyarakat dengan melahirkan generasi penerus bangsa yang berintelektual, inovatif dan profesional di bidang yang ditekuni sebagai model bagi institusi lain dan masyarakat dalam memelihara dan mengelola lingkungan dengan baik. Green campus lahir sebagai pendekatan yang memanfaatkan perguruan tinggi dalam menanamkan pendidikan berkelanjutan dalam kebijakan, manajemen serta segala kegiatan yang dilakukan di dalam kampus tersebut. Pada tahun 2010, Universitas Indonesia mempelopori pendekatannya di Indonesia dengan melahirkan sistem rating dunia penilaian green campus yaitu UI GreenMetric World University Rankings. Sistem rating ini merupakan platform untuk mempromosikan usaha berkelanjutan pada masing-masing institusi perguruan tinggi secara mendunia. Masing-masing kampus dapat mengukur usaha berkelanjutan yang telah dijalankan, dan juga membandingkannya dengan institusi perguruan tinggi lainnya. Kerja sama diantaranya selanjutnya diharapkan dapat terbentuk untuk menghasilkan kampus serta generasi penerus yang lebih peduli lingkungan.

Dalam pelaksanaannya, sistem rating UI GreenMetric ini perlu diperbaharui sesuai dengan kondisi eksisting kampus dan perkembangannya terhadap isu keberlanjutan secara umum sehingga standar ini tetap dapat digunakan untuk mengukur tingkat pencapaian kinerja suatu kampus dengan lebih baik. Mengingat juga bahwa salah satu kendala pelaksanaan green campus di Indonesia adalah berkaitan dengan kurangnya pengetahuan dan pemahaman dari sivitas akademika, berserta staf non-akademik di dalamnya (Wimala et al., 2016). Oleh karena itu, penelitian ini bertujuan untuk mengembangkan kategori Education (ED) dalam UI GreenMetric berdasarkan tinjauan literatur terhadap standar penilaian dunia yang sejenis di Amerika Serikat, yaitu The Sustainability Tracking, Assessment and Rating System (STARS).

\section{TINJAUAN PUSTAKA}

\subsection{UI GreenMetric}

UI GreenMetric World University Ranking merupakan sistem rating penilaian green campus yang dikembangkan oleh Universitas Indonesia pada tahun 2010. Hal ini dimaksudkan untuk mengetahui apa saja program dan kebijakan keberlanjutan yang diberlakukan pada universitas-universitas di seluruh dunia. Pada tahun 2017, sistem penilaian ini telah diikuti oleh 619 peserta di seluruh dunia, dimana 57 institusi atau 9,2\% diantaranya berasal dari Indonesia (UI GreenMetric, 2016).

Dalam penilaiannya, UI GreenMetric mempertimbangkan 6 (enam) kategori yang terdiri dari Setting and Infrastructure (SI), Energy and Climate Change (EC), Waste (WS), Water (WR), Transportation (TR), dan Education (ED). Khusus berkaitan dengan kategori Education (ED), 
beberapa sub kategori yang termasuk ke dalamnya pada saat ini meliputi the ratio of sustainability courses towards total courses, the ratio of sustainability research funding towards total research funding, numbers of sustainability publications, sustainability events and sustainability student organizations, serta existence of sustainability website.

\subsection{The Sustainability Tracking, Assessment \& Rating System (STARS)}

STARS adalah kerangka kerja yang bersifat sukarela untuk membantu perguruan tinggi dalam mengukur kemajuan kinerja perguruan tinggi tersebut dalam program keberlanjutan. STARS dikembangkan oleh badan khusus yang sangat memerhatikan keberlanjutan yaitu The Association for the Advancement of Sustainability in Higher Education (AASHE) pada tahun 2010. STARS dibuat bukan untuk menjadi tujuan akhir bagi para perguruan tinggi, melainkan untuk merangsang para perguruan tinggi untuk berkontribusi di bidang berkelanjutan.

Beberapa kriteria yang dipertimbangkan dalam penilaian green campus menurut STARS v.2.1 meliputi Academics (AC), Engagement (EN), Operations (OP), Planning and Administration (PA), dan Innovation and Leadership (IN). Sejauh mana upaya berkelanjutan yang telah dilakukan oleh suatu institusi perguruan tinggi dapat dilihat dari total skor yang diperoleh dari gabungan skor pada masing-masing kriteria tersebut. Selanjutnya, peringkat pencapaian dapat dibedakan menjadi bronze, silver, gold hingga platinum, dengan total skor sebesar 25, 45, 65, 85, secara berturutan. Kriteria Academics (AC) pada STARS v.2.1, yang mana memiliki tingkatan yang sama dengan kategori Education (ED) pada UI GreenMetric akan ditinjau lebih lanjut pada penelitian ini. Beberapa indikator yang terdapat di dalamnya dapat dilihat pada Tabel 1 berikut ini.

Tabel 1. Indikator STARS v.2.1 dalam Kriteria Academics (AD)

\begin{tabular}{|c|c|c|}
\hline Code & Indicators & Credits \\
\hline $\mathrm{AC} 1$ & \multirow{8}{*}{ Curriculum } & Academic courses \\
\hline AC 2 & & Learning outcomes \\
\hline $\mathrm{AC} 3$ & & Undergraduate program \\
\hline AC 4 & & Graduate program \\
\hline AC 5 & & Immersive experience \\
\hline AC 6 & & Sustainability literacy assessment \\
\hline $\mathrm{AC} 7$ & & Incentives for developing courses \\
\hline AC 8 & & Campus as a living Laboratory \\
\hline AC 9 & \multirow{3}{*}{ Research } & Research and Scholarship \\
\hline AC 10 & & Support for Research \\
\hline AC 11 & & Open access to research \\
\hline
\end{tabular}

\section{METODOLOGI PENELITIAN}

Dalam penelitian ini, UI GreenMetric dijadikan sebagai standar acuan yang selanjutnya akan dikembangkan berdasarkan rujukan standar sejenis yaitu STARS v.2.1. Pengembangan indikator di dalam kategori Edukasi Berkelanjutan (EB) ditentukan atas pertimbangan kondisi eksisting yang seharusnya dilakukan pada institusi perguruan tinggi di Indonesia maupun di luar negeri menggunakan metode deskriptif kualitatif. Dengan sub kategori penilaian yang baru, tahap selanjutnya adalah menentukan bobot penilaian pada masing-masing indikator dan sub indikator yang termasuk di dalamnya sehingga dapat digunakan dalam penilaian green campus di seluruh dunia menggunakan metode Analytical Hierarchy Process (AHP). Metode AHP ini memanfaatkan penilaian dari beberapa pakar yang di bidang pendidikan dan keberlaniutan secara umum. Beberapa pakar bahkan memeqanq sertifikasi Greenship 
Associate (GA) dan Greenship Professional (GP) dari Green Building Council Indonesia (GBCI). Standar penilaian baru selanjutnya diujicobakan pada studi kasus, dalam hal ini di kampus Universitas Katolik Parahyangan (Unpar) untuk tujuan verifikasi. Penilaian kategori Edukasi Berkelanjutan (EB) difokuskan pada Fakultas Teknik, yang terdiri Program Studi (Prodi) Teknik Sipil dan Arsitektur.

\section{HASIL PENGOLAHAN DAN ANALISIS DATA}

\subsection{Hasil Pengembangan dan Pembobotan Nilai}

Pertimbangan yang dilakukan dalam pembuatan standar green campus ditentukan berdasarkan beberapa faktor antara lain dari peraturan yang ada di masing-masing negara asal standar, kondisi lingkungan, serta pendapat para pakar dari masing-masing pembentuk standar. STARS dipilih sebagai standar rujukan dalam penelitian ini mengingat jumlah pendaftar yang telah mencapai 898 institusi perguruan tinggi dari berbagai negara (AASHE, 2017), dan yang paling utama adalah karena kedalaman penilaian yang dimilikinya. Hasil pengembangan kategori, selanjutnya dinamakan sebagai kategori Edukasi Berkelanjutan (EB), mengklasifikan 4 (empat) sub kategori baru, yaitu: akademik berkelanjutan (sustainable academics), pengembangan profesional berkelanjutan (sustainable professional development), dukungan berkelanjutan (sustainable supports), dan penilaian berkelanjutan (sustainable assessment). Tabel 2 (kolom 1, 5 dan 9) menunjukkan indikator dan sub indikator dari masing-masing kategori.

Sub kategori Akademik Berkelanjutan, dan Pengembangan Profesional Berkelanjutan dimaksudkan untuk menjadi solusi atas kendala pelaksanaan green campus di Indonesia yang telah dijelaskan sebelumnya dengan menambah pengetahuan dan pemahaman semua warga kampus, yang terdiri dari para mahasiswa, dosen, dan staf akademik maupun non akademik. Penambahan pengetahuan dan pemahaman ini dilakukan dengan memasukkan ilmu berkelanjutan ke dalam kegiatan akademik yang diterjemahkan dalam kurikulum, baik intrakurikuler, kokurikuler maupun ekstrakurikuler. Kegiatan-kegiatan ini tentu saja mustahil untuk dilakukan jika tidak ada dukungan dari pihak kampus. Oleh karena itu, sub kategori yang ketiga adalah mengenai dukungan yang dapat diberikan baik berupa insentif, beasiswa, dana penelitian/publikasi, maupun pengadaan website khusus sebagai sumber informasi berkelanjutan bagi seluruh warga kampus. Penilaian berkala sebagai langkah akhir juga harus dilakukan untuk mengukur kinerja dari kegiatan-kegiatan yang telah dilakukan. Hal ini dimaksudkan untuk memperbaiki maupun meningkatkan kinerja yang akan dilakukan di masa yang akan datang. Setelah melalui proses pembobotan dengan metode AHP, maka didapatkan hasil pembobotan dari masing-masing tingkatannya yaitu sub-kategori, indikator dan sub-indikator seperti yang terlihat pada Tabel 2 (kolom 2, 6, dan 10).

\subsection{Studi Kasus - Universitas Katolik Parahyangan}

Studi kasus yang ditinjau pada penelitian ini dilakukan di Fakultas Teknik, Unpar. Data yang dibutuhkan dalam mengkaji kinerja penerapan Unpar dalam kategori Edukasi Berkelanjutan (EB) diperoleh melalui wawancara yang dilakukan dengan masing-masing Kepala Program Studi (Kaprodi) di Fakultas Teknik, Lembaga Penelitian dan Pengembangan Masyarakat (LPPM), Biro Kemahasiswaan dan Alumni (BKA), dan Biro Umum Teknik (BUT). Data tersebut juga diverifikasi dengan hasil observasi di lapangan untuk mendapatkan penilaian secara visual dan mendalam terhadap kegiatan-kegiatan yang sudah dilakukan oleh pihak kampus. Seluruh data yang digunakan dalam penilaian green campus ini merupakan data pada tahun 2016. Penilaian dilakukan berdasarkan 5 (lima) kategori yang berkisar dari kategori Sangat Rendah sampai dengan Sangat Tinggi, dengan rentang 20 poin untuk setiap kategori. Hasil penilaian kinerja usaha berkelanjutan di Unpar dapat dirumuskan dalam Tabel 2 berikut ini. Dapat dilihat bahwa 
Pengembangan Kategori Edukasi Berkelanjutan dalam Penilaian Green Campus di Indonesia

Tabel 2. Hasil Penilaian Kategori

\begin{tabular}{|c|c|c|c|c|c|c|c|c|c|c|c|}
\hline Sub Indikator & $\begin{array}{c}\text { Bobot } \\
\text { Sub } \\
\text { Indikator } \\
{[\%]}\end{array}$ & $\begin{array}{c}\text { Penilaian } \\
\text { di } \\
\text { Lapangan }\end{array}$ & $\begin{array}{c}\text { Total } \\
\text { Nilai Sub } \\
\text { Indikator }\end{array}$ & Indikator & $\begin{array}{c}\text { Bobot } \\
\text { Sub } \\
\text { Indikator } \\
{[\%]}\end{array}$ & $\begin{array}{l}\text { Penilaian } \\
\text { Sub } \\
\text { Indikator }\end{array}$ & $\begin{array}{c}\text { Total } \\
\text { Nilai } \\
\text { Indikator }\end{array}$ & Sub Kategori & $\begin{array}{c}\text { Bobot } \\
\text { Sub } \\
\text { Indikator } \\
{[\%]}\end{array}$ & $\begin{array}{c}\text { Penilaian } \\
\text { Sub } \\
\text { Kategori }\end{array}$ & $\begin{array}{c}\text { Total } \\
\text { Nilai } \\
\text { Sub } \\
\text { Kategori }\end{array}$ \\
\hline 1 & 2 & 3 & $\begin{aligned} & 4 \\
= & 2 * 3\end{aligned}$ & 5 & 6 & 7 & $\begin{aligned} & 8 \\
= & 6 * 7\end{aligned}$ & 9 & 10 & 11 & $\begin{array}{c}12 \\
=10 * 11\end{array}$ \\
\hline $\begin{array}{l}\text { Mata kuliah } \\
\text { berkelanjutan }\end{array}$ & 41 & 19 & 7,79 & \multirow[t]{4}{*}{$\begin{array}{l}\text { Kurikulum } \\
\text { berkelanjutan }\end{array}$} & \multirow[t]{4}{*}{50} & \multirow[t]{4}{*}{67,79} & \multirow[t]{4}{*}{33,90} & \multirow[t]{5}{*}{$\begin{array}{l}\text { Akademik } \\
\text { berkelanjutan }\end{array}$} & \multirow[t]{5}{*}{37} & \multirow[t]{5}{*}{43,4} & \multirow[t]{5}{*}{16,06} \\
\hline $\begin{array}{l}\text { Kegiatan } \\
\text { ekstrakurikuler } \\
\text { berkelanjutan } \\
\end{array}$ & 30 & 100 & 30 & & & & & & & & \\
\hline $\begin{array}{l}\text { Aksi kampus } \\
\text { sebagai contoh } \\
\text { bagi para warga } \\
\text { kampus }\end{array}$ & 17 & 100 & 30 & & & & & & & & \\
\hline \multirow{10}{*}{$\begin{array}{l}\text { Organisasi } \\
\text { berkelanjutan } \\
\text { mahasiswa }\end{array}$} & 12 & 0 & 0 & & & & & & & & \\
\hline & & & & $\begin{array}{l}\text { Penelitian } \\
\text { berkelanjutan }\end{array}$ & 50 & 19 & 9,5 & & & & \\
\hline & - & & & - & & & & $\begin{array}{l}\text { Pengembangan } \\
\text { profesional } \\
\text { berkelanjutan } \\
\text { untuk para dosen, } \\
\text { staf akademik dan } \\
\text { non-akademik }\end{array}$ & 22 & 100 & 22 \\
\hline & - & & & $\begin{array}{l}\text { Insentif } \\
\text { pengembangan mata } \\
\text { kuliah berkelanjutan }\end{array}$ & 28 & 0 & 0 & \multirow[t]{5}{*}{$\begin{array}{l}\text { Dukungan } \\
\text { berkelanjutan }\end{array}$} & \multirow[t]{5}{*}{22} & \multirow[t]{5}{*}{20,08} & \multirow[t]{5}{*}{4,42} \\
\hline & - & & & $\begin{array}{l}\text { Beasiswa } \\
\text { berkelanjutan }\end{array}$ & 17 & 0 & 0 & & & & \\
\hline & - & & & $\begin{array}{l}\text { Hibah penelitan } \\
\text { berkelanjutan }\end{array}$ & 31 & 29,17 & 11,08 & & & & \\
\hline & - & & & $\begin{array}{l}\text { Bantuan publikasi } \\
\text { berkelanjutan }\end{array}$ & 14 & 100 & 9 & & & & \\
\hline & - & & & Situs berkelanjutan & 10 & 0 & 0 & & & & \\
\hline & - & & & & - & & & $\begin{array}{l}\text { Penilaian } \\
\text { berkelanjutan }\end{array}$ & 19 & 0 & 0 \\
\hline & & & & & & & & otal nilai kategori & si Berke & $\tan (E B)$ & 42,5 \\
\hline
\end{tabular}


Unpar mendapatkan nilai sebesar 42,5 poin dari total keseluruhan 100 poin, yang berarti masuk ke dalam kategori Sedang.

Hasil akhir penilaian kinerja Unpar disebabkan oleh beberapa faktor, yang dapat dirumuskan sebagai berikut:

1. Mata kuliah berkelanjutan. Fakultas Teknik belum mendapatkan nilai yang baik pada indikator ini. Hal ini dikarenakan ilmu berkaitan berkelanjutan bukan merupakan mata kuliah khusus di Prodi Teknik Sipil dan Arsitektur, namun hanya termasuk ke dalam suatu bahasan dalam topik pembelajaran dalam mata kuliah tertentu. Unpar mendapatkan rasio sebesar 19\% dari total keseluruhan mata kuliah, atau 30 dari 162 mata kuliah yang berkaitan dengan topik.

2. Kegiatan ekstrakurikuler berkelanjutan bertujuan untuk mengetahui keberadaan kegiatan yang dilakukan oleh mahasiswa di luar pembelajaran di kampus. Data yang dicari dari kegiatan ekstrakurikuler adalah antara lain: pengabdian masyarakat, pertukaran pelajar, dan kegiatan lainnya. Fakultas Teknik Unpar antara lain telah melakukan beberapa kegiatan berkelanjutan seperti seminar berbasis berkelanjutan, dan melakukan pengembangan sarana kampung di wilayah Unpar dengan memakai bahan yang bersifat keberlanjutan.

3. Aksi kampus sebagai contoh bagi para warga kampus bertujuan untuk mengetahui adanya usaha penerapan berkelanjutan yang dilakukan oleh pihak kampus yang diterapkan di wilayah kampus. Hal ini diharapkan bisa mengubah kebiasaan harian para warga kampus yang bersifat keberlanjutan. Pada saat ini, telah terbukti bahwa aksi kampus sebagai contoh bagi sivitas akademika telah sukses untuk merubah kebiasaan para sivitas akademika pada kampus tersebut, antara lain seperti sivitas akademika yang tidak merokok di area kampus dikarenakan adanya kampanye berupa banner dan stiker yang bertuliskan dilarang merokok atau sejenisnya, membuang sampah pada tempat yang sudah ditentukan, dipilah berdasarkan jenis sampahnya. Bukti lain bahwa program ini telah berhasil adalah usaha dari pihak kampus dalam membuat sarana-sarana yang ada di area kampus seperti water purifier, tempat sampah daur ulang, bahan untuk acara yang didapat dari bahan bekas acara sebelumnya yang dilakukan oleh Biro Umum Teknik (BUT). Aksi pihak kampus seperti yang sudah disebutkan membuat para mahasiswa khususnya dari Prodi Teknik Sipil dan Arsitektur tergerak untuk menggunakan peralatan yang tidak sekali pakai untuk mengurangi sampah.

4. Organisasi mahasiswa berkelanjutan. Unpar mendapatkan nilai nol dikarenakan tidak adanya organisasi yang memiliki fokus tujuan kepada usaha keberlanjutan. Unpar sempat memiliki organisasi yang memiliki fokus terhadap keberlanjutan pada tahun 2009 yang bernamakan "Parahyangan Green Challenge", tetapi tidak diteruskan untuk tahun-tahun berikutnya tanpa ada alasan yang jelas.

5. Penelitian berkelanjutan bertujuan untuk mengetahui perbandingan antara penelitian yang berkaitan berkelanjutan dengan total penelitian selama setahun terakhir. Fakultas Teknik Unpar mendapatkan rasio sebesar 19\%, yaitu sebanyak 51 dari 267 penelitian gabungan antara Prodi Teknik Sipil dengan Arsitektur. Indikator ini tidak mendapatkan nilai yang sempurna dikarenakan terdapat beberapa komunitas bidang ilmu (KBI) pada masing-masing jurusan sehingga fokus penelitian terbagi ke beberapa bidang masing-masing jurusan. Selain itu, tidak adanya pendanaan khusus kepada penelitian berkelanjutan juga menyebabkan tidak adanya motivasi para sivitas akademika untuk melakukan penelitian yang berbasis berkelanjutan.

6. Pengembangan profesional merupakan indikator yang bertujuan untuk mengetahui keberadaan pengembangan profesional dalam konsep berkelanjutan bagi para dosen dan staf, baik akademik maupun non akademik. Indikator ini mendapatkan nilai nol 
dikarenakan tidak adanya kegiatan berkelanjutan yang ditujukan kepada dosen dan staf yang menyebabkan kurangnya pemahaman dari sebagian staf yang ada di Unpar tentang ilmu yang berkaitan berkelanjutan menurut observasi di lapangan.

7. Insentif untuk pengembangan mata kuliah berkelanjutan mendapatkan nilai nol dikarenakan tidak adanya usaha kampus Unpar dalam memberikan bantuan secara materil kepada pengembangan kurikulum untuk mata kuliah yang berkaitan dengan berkelanjutan.

8. Beasiswa berkelanjutan merupakan indikator yang bertujuan untuk mengetahui keberadaan beasiswa yang bersifat berkelanjutan. Indikator ini mendapatkan nilai nol dikarenakan tidak adanya beasiswa berkelanjutan baik bagi mahasiswa maupun dosen ke institusi perguruan tinggi yang sudah menerapkan topik berkelanjutan ke dalam kurikulumnya.

9. Hibah penelitian berkelanjutan memiliki tujuan untuk mengetahui besaran perbandingan hibah penelitian yang bersifat berkelanjutan dengan total hibah peneilitian yang ada. Indikator ini mendapatkan rasio hibah penelitian berkelanjutan sebesar $11,08 \%$ dikarenakan dari penelitian yang juga tidak sepenuhnya meneliti yang berkaitan berkelanjutan. Hal ini juga disebabkan karena tidak adanya dana berlebih yang dikhususkan untuk penelitian yang berkonsep berkelanjutan, dan juga tidak adanya himbauan agar melakukan penelitian yang berkonsep berkelanjutan selain hanya dimasukkannya 2 (dua) dari 10 (sepuluh) bidang unggulan penelitian dalam Rencana Induk Penelitian (RIP) - Lembaga Penelitian dan Pengabdian Masyarakat (LP2M) Unpar. Dua topik tersebut adalah Perubahan cuaca dan keberagaman hayati (climate change and biodiversity), dan Energi baru dan terbarukan (new and renewable energy).

10. Bantuan publikasi berkelanjutan bertujuan untuk mengetahui keberadaan bantuan kepada sivitas akademika yang melakukan publikasi berkaitan berkelanjutan. Pada penilaian ini mendapatan nilai yang baik, dikarenakan pihak Unpar memberikan bantuan kepada sivitas akademika yang melakukan publikasi secara umum, baik publikasi tersebut bertopik keberlanjutan atau tidak. Besarnya insentif berkisar dari Rp500.000,00 sampai dengan Rp5.000.000,00 berupa publikasi di prosiding seminar dan jurnal, nasional maupun internasional. Pada tahun 2016, Rp35.000.000,00 dari total Rp120.000.000,00 (29,17\%) diberikan kepada penelitian bertema keberlanjutan.

11. Indikator situs berkelanjutan bertujuan untuk mengetahui keberadaan halaman informasi berbasis internet yang khusus berkaitan dengan topik keberlanjutan. Penilaian ini mendapatkan nilai nol dikarenakan tidak adanya situs khusus yang membahas berkaitan berkelanjutan, tetapi Unpar memiliki bahasan berkaitan berkelanjutan pada beberapa waktu tertentu di situs maupun majalah kampus, Media Parahyangan.

12. Penilaian berkelanjutan memiliki tujuan untuk mengetahui keberadaan penilaian berkelanjutan yang diadakan pihak kampus sebagai program untuk evaluasi. Evaluasi ini diperlukan untuk mengukur sejauh mana penerapan konsep keberlanjutan di Unpar pada kurun waktu tertentu. Tentu saja hasil dari evaluasi ini dapat digunakan untuk memikirkan strategi perbaikan yang dapat dilaksanakan di masa yang akan datang untuk mencapai kinerja keberlanjutan yang maksimal. Pada penilaian tahun ini Unpar memiliki nilai nol, dikarenakan tidak adanya pelaksanaan penilaian berkelanjutan.

\section{KESIMPULAN}

Penelitian ini berhasil menghasilkan standar penilaian green campus yang baru pada kategori Edukasi Berkelanjutan (EB), beserta bobot penilaiannya yang selanjutnya dapat digunakan di institusi perguruan tinggi di seluruh dunia. Standar yang dihasilkan adalah lebih menyeluruh dibandingkan dengan UI GreenMetric dengan 4 sub kategori baru, termasuk 8 indikator dan 4 sub indikator di dalamnya. Oleh karena itu, standar ini diharapkan dapat dijadikan sebagai 
bahan masukan bagi pihak Universitas Indonesia untuk memperbaharui UI GreenMetric yang sedia ada bagi hasil keberlanjutan yang lebih maksimal secara lokal maupun global.

Studi kasus di Unpar membuktikan bahwa standar penilaian green campus ini dapat digunakan dengan baik. Nilai yang diperoleh Unpar dalam menerapkan kategori Edukasi Berkelanjutan (EB) sebagai usaha perwujudan kampus hijau adalah sebesar 42,5 dari 100, yang berada dalam tingkatan Sedang. Hal ini selanjutnya dapat menjadi acuan untuk menetapkan strategi perbaikan di masa yang akan datang sesuai dengan visi dan misi dari Unpar. Adapun beberapa usulan strategi yang dapat dilakukan antara lain berupa kegiatan sosialisasi untuk para mahasiswa, dosen maupun staf, studi banding dengan kampus lain maupun dari pihak industri berkaitan dengan pengembangan kurikulum dan penelitian berkelanjutan, dan kerja sama dengan pihak luar berkaitan dengan kegiatan-kegiatan berkelanjutan.

\section{DAFTAR RUJUKAN}

Intergovernmental Panel of Climate Change - IPCC. (2014). Climate Change: Mitigation of Climate Change. Cambridge University Press. Dipetik Maret 20, 2018, dari https://www.ipcc.ch/report/ar5/wg3/.

The Association for the Advancement of Sustainability in Higher Education - AASHE. (2017). STARS Technical Manual. Dipetik Maret 15, 2017, dari https://stars.aashe.org/pages/about/technical-manual.html.

UI GreenMetric. (2016). Guideline of UI GreenMetric World University Ranking 2016. Dipetik Maret, 15, 2017, dari http://greenmetric.ui.ac.id/guidelines/

Wimala, M. et al. (2016). Laporan Penelitian Hibah Unggulan Perguruan Tinggi Dikti: Alat Ukur Green Campus (tidak dipublikasikan). Bandung: LP2M Institut Teknologi Nasional. 